\title{
Doctrine of Stares Decisis in Nigeria: A Step to Conclusion
}

\author{
Peter Ademu Anyebe \\ Nigerian Institute of Advanced Legal Studies, University of Lagos Campus, Akoka, Lagos, Nigeria
}

\begin{abstract}
Sometimes, one has the privilege of writing papers on existing topics like torture and targeted killing, hate speech and hedgehogs. But sometimes one has to pick up a shovel and go back to the dark, featureless coalface of basic jurisprudence. This is such a paper. There is nothing exciting about it except that it addresses an elementary issue that everyone agrees has not been properly resolved and that we will need to think about. Stare decisis has been called many things, among them "a principle of policy", "a series of prudential and pragmatic consideration", and simply "the preferred course". This paper focuses on stare decisis with respect to often overlooked fact that stare decisis is also a step to conclusion. The simple reason for this is that principles established by previous cases are not, however, inviolable. For example, when a court is sufficiently convinced that a previous decision was erroneous, the court may overrule that decision. This paper will conclude that stare decisi is a principle of decision making, not a rule and need not be applied when the precedent at issue is unworkable or badly reasoned.
\end{abstract}

Keywords: Constitution, Court, Judgment, Precedent, Ratio Decidendi , Stare Decisis,

DOI: $10.7176 / \mathrm{JLPG} / 92-03$

Publication date: December $31^{\text {st }} 2019$

\section{Introduction}

There is a grand irony about stare decisis. The doctrine, involves a court's choice to stand by a court's choice to stand by a precedent notwithstanding suspicions about its wrongness (Tribe 2008), enjoys lofty status as the emblem of a stable judiciary. The Supreme Court in the United States has lauded stare decisis as possessing "fundamental importance to the rule of law,(Welch v. Tex. Dept.Highways \& Public Transport 1987), promoting "the evenhanded, predictable, and consistent development of legal principles" (Payne v. Tennessee 1991), and contributing to "the actual and perceived integrity of the judicial process."

Yet despite its billing, stare decisis has a remarkable tendency to incite disagreements that contradict the very principles it is supposed to foster (Montejo v. Louisiana 2009) Therefore, the court repeatedly cautioned that stare decisis is a flexible "principle of policy" as opposed to "an inexorable command" (Payne v. Tennessee) .

As a general rule, the courts adhere to precedents citing the doctrine of stare decisis ("to stand by a decision"). The general rule of stare decisis is not an absolute rule; however, the courts recognize the need on occasion to correct what are perceived as erroneous decisions or to adopt decisions to changed circumstances.

In deciding whether to overrule the precedent, the courts take a variety of approaches and apply a number of different standards, many of them quite general and flexible in application.

This article cites instances in which the courts have overruled precedent as well as instances which they had declined to do so, and sets forth the rationales that the courts have employed.

\section{General Background}

Nigeria operates a written Constitution supported by legislations some of which can be regarded as codes. Despite this, Nigerian judges feel that they must follow the English common law rigid rule of stare decisis. Accordingly, they have arrived that decision by the way they construed the provisions of the written law which stipulate that the High Court shall posses and exercise all the jurisdictions, powers and authorities which are vested in or capable of being exercised by her Majesty's High Court of Justice in England, and that in the absence of any provision to the contrary, procedure and practice for the time being in the High Court of Justice in England shall so far as they can be conveniently applied be in force in the High Courts of this country.

In the United States, the Supreme Court considers stare decisis as the obligation to adhere to past opinions to be "indispensable" to the "rule of law" (Planned Parenthood of Southern Pennsylvania 1992) . In describing the doctrine, the court has explained that "when an opinion issues for the court, it is not only the result but also those portions of the opinion necessary to that result by which we are bound (Seminole Tribe v. .Florida 1996)

The doctrine of stare decisis entrenches a judicial decision in the legal regime of its jurisdiction in order to serve the "social policy" of "continuity in law ...rooted in the psycho logic need to satisfy reasonable expectations". (Halvering v. Hallock 1940)

Furthermore, there is a grand irony about stare decisis. The doctrine which involves a court's choice to stand by a precedent notwithstanding suspicion (or worse) about its wrongness (Laurence Tribe 208), enjoys lofty status as the emblem of a stable judiciary. 


\section{Conceptual clarifications}

This segment concerns with clarifying recurring terms that one will come across often in this paper.

Obiter Dictum-an opinion voiced by a judge on a point of law not directly bearing on the case in question and, therefore, not binding.

Per Incuriam- It refers to a judgment of a court which has been decided without reference to a statutory provision or earlier judgment which would have been relevant.

Precedent-a statement made of the law by a judge in deciding a case. There are two types-binding and persuasive. Binding precedent is one made by higher courts of law that a judge is obliged to follow, while a persuasive are examples brought in from lower courts or from equal level court of another division or district from other lower courts or from equal level of court of another district and may be used for consideration, but higher courts or any courts of another district are not constrained to follow.

Ratio Decidendi-This stands for reason for a decision. It is a legal phrase which refers to the legal, moral, political and social principles used by a court to compose the rationale of a particular judgment. Unlike obiter dicta, the principles of judgment for ratio decidendi stand as potentially binding precedent, through the principle of stare decisis.

\section{Origin and Background of Stare Decisis}

The doctrine of stare decisis arose from a desire for certainty and continuity in law. As early as Bracton and the Year Books of the fourteenth century (Von Moschziska 1924), stare decisis has been termed "at least the everyday working rule of our law" (Cardozo 1960) which generally must be adhered to "if litigants are to have faith in the even handed administration of justice in courts.

The Nigerian legal system just like the United States legal system inherited stare decisis from its English common law ancestor (William Consovoy 2002). While there are many reasons a judge might follow the reasoning of an earlier decision, English Courts, in the early $18^{\text {th }}$ century "began to speak of a qualified obligation to abide by past decisions (Thomas Lee 1999). William Blackstone's Commentaries, written during the same period, began to refer to "an established rule to abide by former precedents, where the same points came again in litigations (William Blackstone). By the late $18^{\text {th }}$ century when the founders were designing the United States judicial system, stare decisis was "firmly in place" in England.(Wallace Jefferson 2004). The notion that judges ought generally to abide by relevant precedents developed over several centuries (Allen 1964) Blackstone wrote in the eighteenth century that it was "an established rule to abide by former precedents, where the same points come again in litigation.....unless flatly absurd or unjust" (Blackstone Commentary)

Parke J. said in Mirehouse v. Rennel (1833) as follows:

Our common law system consists in the applying to new combinations of circumstances those rules of law which we derive from legal principles and judicial precedent; and for the sake of attaining uniformity, consistency and certainty, we must apply those rules, where they are not plainly unreasonable and inconvenient, to all cases which arise; and we are not at liberty to reject them, and to abandon all analogy to them, in those to which they have not yet been judicially applied, because we think that the rules are not as convenient and reasonable as we ourselves could have devised.

The practice of relying on precedents in equity was also established in the eighteenth century. The modern strict rules whereby a single precedent can be binding and precedents can be binding even if "unreasonable and inconvenient" developed in the nineteenth and twentieth centuries. Important factors were the regularization of and improvements in law reporting following the establishment of the Incorporated Council of Law Reporting and the reorganization of the courts with a clear hierarchical structure in the latter part of the nineteenth century. The rule that appellate courts are normally bound by their own previous decisions was clearly established for the House of Lords in 1898 but was later changed in 1964 and for the Court of Appeal in 1944.(Bailey et al 2007)

\section{a. Doctrine of Stare Decisis: Understanding the concept}

In an article published in 1987, (Fred Schauer) made an interesting suggestion, which I think opens the prospect of a better understanding of stare decisis than we have had hitherto. He said thusly:

An argument from precedent seems at first to look backward. The traditional perspective on precedent ...has therefore focused on the use of yesterday's precedents in today's decisions. But in an equally if not more important way, an argument from precedent looks forward as well, asking us to view today's decision as a precedent for tomorrow's decision makers. Today is not only yesterday's tomorrow; it is also tomorrow's yesterday

One of the most important doctrines in Western law is that of stare decisis, a Latin term of art which means "to stand by decide case; to uphold precedents; to maintain former adjudications"( Henry Campbell Black 1910).

A recapitulation from (The American Register 1886) will give a better understanding of the concept of the 
doctrine of stare decisis:

The policy of the courts and the principle upon which rests the authority of judicial decisions as precedents in subsequent litigations, is embodied in the maxim, stare decisis et non quieta movere-to abide by the precedent, and not to disturb settled points. Its meaning is that when a point of law has been once solemnly and necessarily settled by the decision of a competent court, it will no longer be considered open to examination or to a new ruling, by the same tribunal or those which are bound to follow its adjudication. The reasons underlying this rule are stated by Chancellor KENT in a much quoted passage from the commentaries as follows: A solemn decision upon a point of law, arising in any given case, becomes an authority in a like case, because it is the highest evidence which we can have of the law applicable to the subject, and the judges are bound to follow that decision as long as it stands unreversed, unless it be shown that the law was misunderstood or misapplied in that particular case. If a decision has been made upon solemn argument and mature deliberations, the presumption is in favour of its correctness; and the community has a right to regard it as a just declaration or exposition of the law, and to regulate their actions and contracts by it. It would, therefore, be extremely inconvenient to the public, if precedents were not duly regarded and implicitly followed. It is by the notoriety and stability of such rules that professional men can give safe advice to those who consult them

In modern jurisprudence, however, it has come to take on a life of its own with all precedents being presumed to be well founded, unbiased legal decisions, rather than political decisions, and presumed to have both the authority of the constitutional enactments on which they are based so that later precedents are presumed to be more authoritative than others.

The principle of stare decisis enjoins adherence by lower courts to doctrinal rules established by superior courts. It is based on the principle that once a question of law has been examined and decided, it should be deemed settled and closed to further argument. Basically it is bar to any attempt to relitigate the same issues.

The principle of stare decisis dictates that in the absence of a special justification for overruling a prior decision, a court must follow its prior decisions even though a majority of the court as currently constituted, believes that the prior decision was wrongly decided (Sedler 1911).

There is a grand irony about stare decisis. The doctrine, which involves a court's choice to stand by a precedent notwithstanding suspicion (or worse) about its wrongness (Laurence Tribe 2008), enjoys lofty status as the emblem of a stable judiciary. Indeed the Supreme Court has lauded stare decisis as possessing "fundamental importance to the rule of law" (Welch Tex Dep), promoting "the evenhanded, predictable, and consistent development of legal principles" (Payne v. Tennessee 1991), and contributing to "the actual and perceived integrity of the judicial process." (Cardozo 1921; Farber 2006)

Essentially, precedent is that doctrine which requires a judge, in resolving a particular case before him, to follow the decision in a previous case, where the fact situations in the two cases are similar (Gall 1977). Essentially, the operation of the doctrine of stare decisis is best explained by reference to the English translation of the Latin phrase. "Stare decisis" literally translate as "to stand by decided matters". However, the phrase "stare decisis" is itself an abbreviation of the Latin phrase "stare decisis et non quieta movere" which translates as "to stand by decisions and not to disturb settled matters".

The rule of judicial precedent otherwise known as stare decisis is well rooted in Nigerian jurisprudence. It is well settled principle of judicial policy which must be strictly adhered to by all lower courts. While lower courts may depart from their own decisions reached per incuriam, they cannot refuse to be bound by decisions of higher courts even if those decisions were reached per incuriam (Dalhatu v.Turaki 2003).

The English theory of judicial precedent is that a decision of a judge, once given on a question of law, binds both that judge him and subsequent judges in lower courts to decide the same question in a similar manner. (Hanbury 1949). But any judgment of any Court is authoritative only as to that part of it, called ratio decidendi, which is the principle considered to form the real basis of the decision in question. Obiter dicta have no binding force and their authority varies with the personal standing of the judge who pronounced them (Elias 1993).

The American common law doctrine has been well stated as follows:

The general American doctrine behind stare decisis, then is that a court is not inexorably bound by its own precedents, but in the interests of uniformity of treatment to litigants, and of stability and certainty in the law, a court will follow the rule of law which it has established in earlier cases unless clearly convinced that the rule was originally erroneous or is no longer sound because of changed conditions and that more good than harm would come by departing from precedent.

The formulation emphasizes that stare decisis if it can be considered a rule at all, is at most a rule of policy 
that requires the balancing of a variety of factors in the process of deciding whether a particular precedent or line of precedents should be followed or rejected (The Federalist No. 78 1961).

The doctrine of judicial precedent (otherwise called stare decisis) requires all subordinate courts to follow decisions of superior courts even where these decisions are obviously wrong having been based upon false premise; this is the foundation on which inconsistency of our judicial decision is based (Ngwo v. Monye 1970). The underlying logic of this doctrine is to maintain consistency and to avoid uncertainty. The guiding philosophy is that a view which has held the field for a long time should not be disturbed only because another view is possible. This has been aptly pointed out by Chandrachud, C.J. in Waman Rao v. Union of India (1981) thus:

For the application of the rule of stare decisis, it is not necessary that earlier decision or decisions of longstanding should have considered and either accepted or rejected the particular argument which is advanced in the case on hand. Were it so, the previous decisions could more easily be treated as binding by applying the law of precedent and it will be unnecessary to take resort to the principle of stare decisis. It is therefore sufficient for invoking the rule of stare decisis that a certain decision was arrived at on a question which arose or was argued, no matter on what reason the decision rests or what is the basis of the decision. In other words, for the purposes of applying the rule of stare decisis, it is unnecessary to enquire or determine as to what was the rationale of the earlier decision which is said to operate as stare decisis.

The doctrine of stare decisis is a very valuable principle of precedent which cannot be departed from unless there are extraordinary or special reasons to do so (Manganese Ore (India) Ltd. v. Regional Assist 1976).

In the United States which uses the common law system in its courts and to a lesser extent in its federal courts, the Ninth Circuit Court of Appeals has stated (United States Internal Revenue Services v. Osborne 1996):

Stare decisis is the policy of the court to stand by precedent, the term is but an abbreviation of stare decisis et quieta non movere-"to stand by and adhere to decisions and not disturb what is settled. Consider the word "decisis". The word means literally and legally, the decision. Nor is the doctrine stare dictis, it is not "to stand by or keep to what was said". Nor is the doctrine stare rationibus decidendi"to keep to the rationes decidendi of past cases". Rather, under the doctrine of stare decisis, a case is important only for what it decides-for the "what", not for the "why" and not for the "how". Insofar as precedent is concerned, stare decisis is important only for the decision, for the detailed legal consequence following a detailed set facts.

In other words, stare decisis applies to the holding of a case, rather than to obiter dicta ("things said by the way"). As the United States Supreme Court has put it "dicta may be followed if sufficiently persuasive but are not binding (Central Green Co. v. United States 1935).

The doctrine of binding precedent or stare decisis is basic to English legal systems that derived from it such as those of Australia, Canada, Hong Kong, New Newzeland, Pakistan, Singapore, Malaysia, South Africa, Nigeria, Ghana, etc.

A precedent is a statement made by a judge in deciding a case. The doctrine states that within the hierarchy of the English courts a decision by a superior court will be binding on inferior courts. This means that when judges try cases they must check to see if similar cases have been tried by a court previously. If there was a precedent set by an equal or superior court, then a judge should obey that precedent. If there is a precedent by an inferior court, a judge does not have to follow it, but may consider it. The dynamic element of the doctrine is an acknowledgement of the fact that the law must grow and conform to the norms, institutions and sense of justice of the times if it is to command obedience and respect. The static element is a reminder that stability and certainty, rather than growth and change, are often higher values and, in any event, that judge-made growth and change must be incremental (Shapiro 1968).

The doctrine of judicial precedent (otherwise called stare decisis) requires all subordinate courts to follow decisions of superior courts even where these decisions are obviously wrong having been based upon false premises; this is the foundation on which the consistency of Nigeria's judicial decision is based (Ngwo v. Monye 1970). In Clement v. Iwuanyanwu (1989), the Supreme Court of Nigeria defined stare decisis to mean abiding by a former precedent where same points come again for litigation. The doctrine presupposes that the law has been solemnly declared and determined in the former case thereby, in a hierarchical judicial arrangement, precluding Judges of subordinate courts from changing what has been determined. Also, stare decisis has been defined by the Supreme Court in the case of Osakue v. Federal College of Education (Technical) Asaba (2010), as follows:

Stare decisis means to abide by the former precedents where the same points came again in litigation. It presupposes that the law has been solemnly declared and determined in the former case. It does preclude the judges of the subordinate courts 
from changing what has been determined. Thus, under the doctrine of stare decisis,

lower courts are bound by the theory of precedent.

Generally, there are two types of stare decisis: vertical stare decisis and horizontal stare decisis. vertical stare decisis require lower courts to follow the precedents of of higher courts when faced with indistinguishable facts. For example in the United States, after the Supreme Court's decision in Roe v. Wade (1973), all federal and state courts had to recognize a woman's fundamental rights to an abortion during the first trimester of pregnancy without state interference despite any strong moral, philosophical, or legal disagreements judges may have had with the decision. In contrast, a horizontal stare decisi involves a court following its precedent.

\subsection{Functions of Stare Decisis}

A variety of arguments are made in defence of reliance on precedent. Chief Justice Rehnquist, in the 1991 Payne v. Tennessee case, provided this rationale for precedent and when to accept or reject it. Stare decisis is the preferred course because it promotes the evenhanded, predictable, and consistent development of legal principles, fosters reliance on judicial decisions and contributes to the actual and perceived integrity of the judicial process (Payne v. Tennessee 1986).

Although the doctrine of stare decisis does not prevent re-examining and, if need be, overruling prior decisions, "it is .... fundamental jurisprudential policy that prior applicable precedent usually must be followed even though the case, if considered anew, might be decided differently by the current justices. This policy ...'is based on the assumption that certainty, predictability and stability in the law are the major objectives of the legal system; i.e. that parties should be able to regulate their conduct and enter into relationships with reasonable assurance of the governing rules of law" (Moradinshalal v. Fireman Insurance Coy 1988). Thus the courts, generally speaking, attempt to avoid overturning precedent, since adherence to it "permits society to presume that bedrock principles are founded in the law rather than in the proclivities of individuals, and thereby contributes to the integrity of the United States Constitutional system of government both in appearance and in fact.

The use of stare decisis allows even judges of general jurisdiction to develop specialized areas of experts within the law. Judges can allocate their human capital in such a way as to become experts in a particular field, such as admiralty, criminal procedure, or securities regulation, confident that they can rely on other judges' expertise in the areas in which they have not specialized. Therefore, the practice of stare decisis permits judges to "trade" information among one another, thereby enabling them to develop areas of comparative advantage (Macey 1989).

The doctrine also serves as an important check on judges. As Alexander Hamilton explained in Federalist No. 78

To avoid an arbitrary discretion in the courts, it is indispensable that they should be bound down by strict rules and precedents, which serve to define and point out their duty in every particular case that comes before thems.

In Union of India v. Raghubir Singh (1989), the Supreme Court of India enunciated the importance of doctrine of binding precedent in the development of jurisprudence of law thusly:

Taking note of the hierarchical character of the judicial system in India, it is of paramount importance that the law declared by this court should be certain, clear and consistent. It is commonly known that most decisions of the courts are of significance not merely because they constitute adjudication on the rights of the parties and resolve the dispute between them, but also because in doing so they embody a declaration of law operating as a binding principle in future cases. In this latter aspect lies their particular value in developing the jurisprudence of law.

Further, in Hari Singh v. State of Haryana (1993), the court stated the importance of consistent opinions in achieving harmony in judicial system:

It is true that in the system of justice which is being administered by the courts, one of the basic principles which has to be kept in view, is that courts of coordinate jurisdiction, should have consistent opinions in respect of an identical set of facts or on a question of law while exercising the same jurisdictions, then instead of achieving harmony in the judicial system, it will lead to judicial anarchy.

The doctrine of binding precedent has the merit of promoting certainty and consistency in judicial decisions and enables an organic development of the law, besides providing assurance to the individual as to the consequence of transactions forming part of his daily affairs. There is therefore, the need for a clear and consistent enunciation of legal principle in the decisions of a court (Union of India v. Raghubir).

The doctrine of binding precedent) has the merit of promoting certainty and consistency in judicial decisions. The pronouncement of law by a larger Bench of the Supreme Court is binding on a Division Bench especially where the particular determination not only disposes of the case, but also decides a principle of law. It 
will therefore be inappropriate to relitigate the very issue or a particular provision, which had already been considered and upheld (Tiverton Estates v. Wearwell Ltd 1975).

The doctrine of stare decisis is fully entrenched in the Nigerian jurisprudence to ensure certainty of the law. Therefore, it would be wrong for the Judge of a High Court before whom a decision of the Supreme Court is cited to deliberately and consciously refuse to apply it because he believes that the Supreme Court is wrong in its decision in the case. Consequently, while under the doctrine the decision of a higher court may be criticized by the Judge of a lower court, the Judge is nonetheless bound to follow and apply such decision in the case before him. He has no right to disregard the decision or side track it (Dalhatu v. Turaki).

Essentially, the purposes and advantages of the doctrine of stare decisis are as follows:

- To provide for certainty and predictability in the law;

- To provide for continuity and stability in the law;

- To provide for consistency in the law;

- To provide for the possibility of growth in the law in that as the new factual circumstances occur, this gives rise to new statements of principle.

It has been suggested that a further advantage of the doctrine is that it contributes to the growth of case law containing an abundance of detail and possessing a practical character (Wood Manufacturing Co. Ltd v. The King 1951).

To be sure, there are certain disadvantages arising out of the operation of the doctrine of stare decisis:

- Rigidity and inflexibility in the law;

- The danger of illogical distinctions; and

- The vast magnitude and complexity of detail in the common law.

The United States Supreme Court has observed that stare decisis is generally "the preferred course because it promotes the evenhanded, predictable, and consistent development of legal principles, foster reliance on judicial decisions, and contributes to the actual and perceived integrity of the judicial process (Hohn v. United States 1998).

Among the greatest effects of stare decisis, is to justify the court in treating some questions as settled...The doctrine liberates the Justices from what otherwise would be a constitutional obligation to reconsider every potential disputable issue as it were being raised for the first time (Kozel 2010).

\subsection{The operation of Stare Decisis}

Basically, under the doctrine of stare decisis, the decision of a higher court within the same provincial jurisdiction act as binding authority on a lower court within that same jurisdiction. A decision of a court of another jurisdiction, however, can only act as persuasive authority and therefore relevant (Adigun v. A.G., Oyo State No. 2, 1987).

In Nigeria, the principle of stare decisis or binding force of precedent makes it obligatory on all lower courts, however strongly they may be opposed to a judgment of a higher court which comes before them for consideration, to accept the binding effect of that judgment upon their courts. A lower court is free to express its own views on the issue of law concerned but must as a necessity give its decision in accordance with the binding decision of the court superior in authority and jurisdiction to it. The lower court is not entitled to jettison the decision of the court with superior jurisdiction on the slightest pretext or substitute that decision with its own. That is a primary requirement of "judicial discipline" under the principle of stare decisis (Ritz \& Co. KG v. Techno 1999). This principle of blindness of decisions of higher courts on lower courts was well articulated by Tobi, J.C.A. (as he then was) in (Onymeizue v. Ojiako 2000)as follows:

Nigeria courts, operating the common law, religiously follow the doctrine of precedent in the enforcement of the judicial process. As a matter of law and tradition, they adore the doctrine. Under the doctrine, decisions of a higher court are binding on the inferior courts. Put in another language, decision of a higher court is binding on a lower court. Thus the decisions of the Supreme Court are binding on the Court of Appeal and all other courts below. Decisions of the high courts are generally binding on Magistrate Courts and other inferior courts.

In further stressing the principle of stare decisis, the Supreme Court in the case of Okoniji v. Mudiaga Odge 1985 , held as follows:

In the hierarchy of courts in this country, as in all other free common law countries, one thing is clear, however, learned a lower court considers itself to be and however, contemptuous of the higher court, that lower is still bound by the decision of the higher court...I hope it will never happen again whereby the Court of Appeal in this country or any lower court for that matter would deliberately go against the decision of this court and in this case, even to the extent of not considering the decision when 
those of this court were brought to the notice of that court. This is the discipline of

law. This is what makes the law certain and prevents it from being an ass.

Therefore, the Supreme Court of Nigeria is the highest court of appeal in Nigeria and its decisions bind every court, authority or person in Nigeria. However, there are situations when the Supreme Court's decision may not bind lower courts. Hence, where the principles enunciated in the Supreme Court decision are not relevant or applicable to the issue or issues arising for determination in the case before the Court of Appeal or any other lower court, it is not necessary that the Court of Appeal or any other lower Court should apply the aforesaid principles (7UP Bottling Co. Ltd. Abiola \& Sons 1995).

The United States Supreme Court is equally the highest court in the land. Therefore, its decisions are binding on all courts in the United States.

The duty of the lower court is to apply the ratio decidendi of a case decided by an appellate or higher court whether it agrees with it or not. A lower court can only avoid the decision of a higher court where it is possible to distinguish the case from the case the lower court is dealing with. The basic fact is that it will be an act of judicial impertinence for a lower court to refuse to follow the decision of a higher court because the lower court thinks that the decision of the higher court is wrong or given per incuriam (Chief Effiong Le Nelson v. Chief Okon Ebanga 1998). Consequently, where the decision of a higher court is given per incuriam, a lower court is bound to follow it (Ndili v. Akinsunmade 2000). Therefore, for a judge of a lower court to refuse to abide by the decision of a superior court amounts to an abominable act, contrary to the ethics of his appointment. Such behaviour should not be condoned. Even if the judge disagrees with the decision of the superior court, under the doctrine of stare decisis, he is bound to follow it.

\subsection{Operation of stare decisis in Civil Law Countries}

The doctrine that holdings have binding precedential value is not valid within most civil law jurisdictions as it is argued that this principle interferes with the right of the judges to interpret law and the right of the legislature to make law. Most such systems, however, recognize the concept of jurisprudence constante, which argues that even though judges are independent, they should rule in a predictable and non-chaotic manner. Therefore, judges' right to interpret law does not preclude the adoption of a small number of selected binding case laws.

\section{Stare Decisis-a step to conclusion}

The doctrine of stare decisis arose from a desire for certainty and continuity in the law. As early as Bracton and the Year Books of the fourteenth century (Von Moschzisker 1924), stare decisis has been termed "at least the everyday working rule of our law Cardozo 1964) which must be generally adhered to "if litigants are to have faith in the even handed administration of justice in the courts." With one exception, the doctrine has never called for complete adherence to prior decisions. Blackstone's position was that "precedents and rules must be followed, unless flatly absurd or unjust."

The doctrine of stare decisis is a legal principle tending to stabilize the law so that all may know what it is and act accordingly. It was once dependable but has become inconsistent and unstable. Only recently, it was referred to as a "social policy...rooted in the psychologic need to satisfy reasonable expectations"( Helvering v. Hallock 1940).

According to E.H.Wilson, as long as men continue to think, there will be differences of opinion as well as in science and theology. Legal questions cannot be solved by mathematical formulae; however, neither should the law be made so uncertain by the varying opinions of judges, whereby sweeping and unpredictable charges are announced, and overturning long established principles, whether the diversities in view point be legal or ideological or political, that a prospective litigant, with knowledge of the latest decision, can do no better than guess as to what the law may be after his case has run the gantlet of the lower courts and has come to the scrutiny of last resort (Wilson 1945).

Stare decisis, a Latin word for "let the decision stand"- in common law, the doctrine under which courts adhere to precedent on question of law in order to ensure certainty, consistency and stability in the administration of justice. Since no court decision can have universal application, the courts, in practice, must often decide that a previous decision does not apply to a particular case even though the facts and issues appear to closely similar. A strict application of stare decisis may lead to rigidity and to legal hair splitting, whereas too much flexibility may result in uncertainty.

The American common law doctrine has been well stated as follows:

The general American doctrine behind stare decisis, then, is that a court is not inexorably bound by its own precedents, but, in the interests of uniformity of treatment to litigants, and of stability and certainty in the law, a court will follow the rule of law which it has established in earlier cases unless clearly convinced that the rule was originally erroneous or is no longer sound because of changed conditions and that more good than harm would come by departing from precedent (Moore and Oglebay 1941).

According to Noland (2019), the dynamic element of the doctrine is an acknowledgment of the fact that the 
law must grow and conform to the norms, institutions and sense of justice of the times if it is to command obedience and respect. The static element reminds us that stability and certainty, rather than growth and change are often higher values and, in any event, that judge-made growth and change must be incremental.

Although the Supreme Court in the United States has noted that stare decisis "is of fundamental importance to the rule of law, it is "not...an inexorable command." (Lawrence v. Texas 2003) Thus, some scholars caution against the strict application of stare decisis, concerned that this would prevent courts from correcting errors of judges and modifying decisions that are no longer consistent with modern day social policy, politics, and law (Barnhart 2005)

As far back as 1898 the House of Lords finally agreed to be bound, by its own decisions. The classical case in mind is the case of London Street Tramways v. London County Council (1898). That was the situation for almost a century until 1966 when it had to qualify its stand by the following statement made by Lord Gardner, L.C. on behalf of the House ( i.e. on behalf of himself and The Lords of appeal in Ordinary):-

Their Lordships regard the use of precedent as an indispensable foundation upon which to decide what is the law and its implication to individual cases. It provides at least some degree of certainty upon which individuals can rely in the conduct of their affairs, as well as a basis for orderly development of legal rules. Their Lordships nevertheless recognize that too rigid adherence to precedent may lead to injustice in a particular case and also unduly restrict the proper development of the law. They propose therefore, to modify their present practice and, while treating formal decisions of this house as normally binding, to depart from a previous decision when it appears to be right to do so (Practice Statement 1966).

They proposed therefore to modify their present practice and, while treating former decisions of the House as normally binding, to depart from a previous decision when it appears right to do so.

The Practice Statement definitely had a strong persuasive effect on the attitude of the Supreme Court of Canada. Thus, in the case of Harrison v. Carswell (1975), Mr. Justice Laskin, the Chief Justice of Canada, stated that the issue for determination in the case was "whether this court must pay mechanical deference to stare decisis". The Chief Justice then proceeded to expand on that issue and stated as follows at page 683:

This court, above all others in this country, cannot be simply mechanistic about previous decisions, whatever is the respect it would pay to such decisions. What we would be doing here, if we were to say that Regina v. Peters (1971), 17 D.L.R (3d) 128n (Can), because it was so recently decided, has concluded the present case for us, would be to take merely one side of a debatable issue and say that it concludes the debate without the need to hear the other side.

I do not have to call upon pronouncements of members of this court that we are free to depart from previous decisions in order to support the pressing need to examine the present case on its merit...But, above all, this court has not shown itself to be timorous in tackling important issues where it could be said, with some justification, that an important consideration was absent from an earlier judgment, even a recent one, upon which reliance was placed to foreclose examination of a similar issue in a subsequent case.

In summary, therefore, it is probable that the Supreme Court of Canada will not, in future if not present, regard itself as being bound by stare decisis.(Gall 1977). Take for example, the controversial comments of Judge Matheson in the case of Regina v. Beaney (1969):

Thus, unless there is competent legislation imposing on the courts a strict rule of stare decisis, whether one court is bound to decide the rationes decidendi of the decisions of another court cannot be a matter of law but only of judicial attitudes and practical convenience. Just as the Parliament cannot enact a law that Parliament cannot repeal, the courts cannot be the author of a true law of stare decisis. A rule or law that imposes a legal obligation on a court to follow and apply certain precedents must have its source outside that court.

\subsection{Conclusiveness of Stare Decisis}

The Supreme Court in Nigeria cannot depart from its previous decision because of qualitative and persuasive arguments of counsel. This was the pronouncement of Ayoola, J.S.C (as he then was) in the case of Adisa $v$. Oyinlola (2000). However, it may be emphasized that the court has not laid down a hard and fast rule exhausting the area within which to warrant a departure from a previous decision. Each case must be decided on its special fact and circumstances with a view to avoiding perpetuating injustice.

In the same vein where a decision is impugned on the ground that it has been arrived at by the court only because it had acted in ignorance or concealment of an authority, statutory or otherwise, which is binding on the 
court, the decision is said to have been given per incuriam and constitutes a special case where the court is not bound to apply the principle of stare decisis. Thus in Moraline Ltd v. Wakeling (1955), Lord Evershed, M.R., observed as follows:

As a general rule the only cases in which decisions should be held to have been

given per incuriam are those decisions given in ignorance or forgetfulness of some inconsistent statutory provision or of some authority binding on the court concerned.

Similarly, it was held in Nicholas $v$. Penny (1950) that where material cases or statutory provisions, which show that a court had decided a case wrongly, were not brought to its attention the court is not bound by that decision in a subsequent case (Ngwo v. Monye 1970). See also in this connection R. v. Northumberland Compensation Appeal Tribunal ex-parte Shaw (1951) where it was held that where a decision is given per incuriam it does not possess for the court any binding effect on the court concerned.

In the United States, many judges fervently advocate the importance of stare decisis in the case of Planned Parenthood v. Casey (1992) where three of the Justices addressed the prospect of overturning the abortion decision in Roe v. Wade (1973). They devoted a long section of their argument to the issue of stare decisis, insisting at the outset that "the very concept of the rule of law underlying the United States Constitution requires such continuity over time that a respect for precedent is, by definition, indispensable. For example, Justice Cardozo once wrote, "the labour of judges would be increased almost to the breaking point if every past decision could be reopened in every case, and one could not lay one's own course of bricks on the secure foundation of the courses laid by others who had gone before him" (Cardozo 1921) Nevertheless, reversals "must be orderly process of law (United States v. United Mine Workers 1947) and should not derive from mere private judgment (Graves v. New York 1939). Justice Frankfurter perceived that stare decisis is a "principle of policy and not a mechanical formula (Helvering v. Hallock 1940) that requires the delicate balancing of a variety of factors. He brought to this task a keen sense of history which reminded him that the court seldom wrote on a clean slate ( Galvan v. Press 1954), although he recognized that a single decision (Kovacks v. Cooper 1949) or a few sporadic decisions (Toucey v. New York 1941) could not check the courts power to examine an issue from a fresh viewpoint and with an eye on the present. Where however, a uniform course of decisions held that the ex post facto clause had no application to deportation, he was unwilling to disregard precedent, although as a first impression he might have decide the question otherwise (Unites States v. Bomett 1964). Justice Frankfurter was more reluctant to question or overrule a case that had been comprehensively briefed and argued and thoroughly rebutted by the court (Adamson v. California 1974). Also, if a decision has proved workable in practice (and if its theoretical underpinnings have not been eroded), Justices may be unwilling to overrule it despite disagreement on the merits. For example, in refusing to overrule its landmark decision in Miranda v. Arizona (1966), the court in Dickerson v. United States (2000) pointed to the fact that Miranda warnings had become "embedded in routine police practice to the point where the warnings have become part of our national culture". Chief Justice Rehnquist's opinion for the court stated that "principles of stare decisis weigh heavily against overruling" Miranda "whether or not we would agree with Miranda's reasoning and its resulting rule, were we addressing the issue in the first instance."

Reliance interests can sometimes tip the scales against overruling. In declining to overrule a 25 year-old precedent interpreting the Commerce Clause as prohibiting a State from collecting use taxes on out-of-state mail order businesses that do not have a physical presence within the state, the court stated that the rule had "engendered substantial reliance and has become part of the basic framework of a sizeable industry (Quill Corp. v. North Dakota 1992)."

Although the newness of a precedent is sometimes seen as reducing its immunity from overruling, the oldness of a precedent does not always prevent its overruling. For example, the Court in Erie Railroad v. Tomkins (1938) overruled Swift v. Tyson (1842), a decision then almost 100 years old, on the basis that its recognition of a federal common law was unconstitutional, and had led to undesirable results in commercial activities. Indeed, the older a precedent is, the more possibility there is that its doctrinal underpinnings will have been eroded through developments in the law (Hughs v. Oklahoma 1979).

Age of a precedent can provide the opportunity for its reinforcement as well as for its erosion. A precedent "that has become integrated into the fabric of the law" is more likely to have engendered reliance interests, and its overruling may even damage "the ideal of the rule of law (Adarand Constructors v. Pena 1995)."

As recent as in 1994, and 1996, majority opinions of the United States Supreme Court adopted Justice Brandeis dissent in Burnet (Burnet v. Coronado Oil and Gas 1932):

In the words of Mr. Justice Brandeis: Stare Decisis is usually the wise policy, because in most matters it is important that the applicable rule of law be settled than that it be settled right.... This is commonly true even where the error is a matter of serious concern, provided correction can be made by legislation. But in cases involving the Federal Constitution, where correction through legislative action is practically impossible, this Court has often overruled its earlier decisions. The Court 
bows to the lessons of experience and the force of better reasoning, recognizing that the process of trial and error, so fruitful in the physical sciences, is appropriate also in the judicial function.

Also, in 1986, a majority of justices on the Supreme Court granted a criminal defendant a new trial, 23 years after he was convicted of murder, although there was no allegation of unfairness in the first trial. Justice Powell, joined by Chief Justice Burger and Justice Rehnquist, dissented:

Adhering to precedent: is usually the wise policy, because in most matters it is more important through the applicable rule of law be settled than it be settled right". Accordingly, "any departure from the doctrine of stare decisis demands special justification (Arizona v. Rumsey 1984)". Nevertheless, when governing decisions are badly reasoned or conflict with other, more recent authority, the Court "has never felt constrained to follow precedent (Smith v. Allwright 1994)". Instead, particularly where constitutional issues are involved, "this Court has shown readiness to correct its errors even though of long standing (United States v. Barnet 1964).

\section{The Factors that guide the courts in overruling precedents}

- The court should first determine the propriety of a reversal in the circumstances of the case before it. The factors to consider therein are as follows: $>$ Whether the issue has been fully argued and briefed and $>$ Whether a reversal is necessary because the precedents are not distinguishable on some valid and meaningful ground, and there are no other grounds for the decision.

$>$ Some judgments must be made of the weight to be accorded to the precedent or precedents involved. The elements that will influence the judgment include:

$>$ The age of the doctrine;

$>$ The number of cases upholding or applying the doctrine;

$>$ The degree of support that the doctrine has historically enjoyed; and

$>$ The thoroughness with which the doctrine has been considered in previous cases.

- The nature of the constitutional question involved has a bearing on the weight to be given to prior interpretations.

- The court must find some substantive basis for reversal. Its attention should be directed, for example, to any:

$>$ New history or learning which casts doubt on the validity of the prior rule;

$>$ New economic and political conditions which render the rule unfit for continued application;

$>$ New policies or philosophies which undermine the doctrine's logical foundation; and

$>$ Unfavourable experience with the rule.

- Finally, the court must be constantly aware of the consequences of the alternative courses. These include:

$>$ The practical consequences of a failure to overrule;

$>$ The logical consequences of the new doctrine; and

$>$ The practical consequences of an overruling (Miranda v. Arizona 1966).

\subsection{Some notable examples of where precedents were overruled}

* Minersville School District v. Gobitis (1940) held that a public school could expel pupils who refused to salute the flag because they were Jehovah's witnesses. This case was later overruled by West Virginia State Board of Education v. Barnet (1943).

* Plessy v. Ferguson (1846) held that "equal but separate" segregated facilities were constitutionally permissible. Overruled by Brown v. Board of Education of Topeka, Shawnee County, Kan (1954), where the Court arguably forced social change more than it responded to it. The Court abandoned its interpretation of the Equal Protection Clause as allowing "separate but equal" treatment of the races and held that racial segregation in the public schools was inherently unequal.

* Hoyt v. State of Florida (1961) allowed the exclusion of women from juries. Overruled by Taylor v. Louisiana (1975) held that it was no longer tenable to hold that women as a class may be excluded to given automatic exemptions based solely on sex if the consequence is that criminal jury venires are almost totally male. To this extent the contrary implications cannot be followed of the prior cases, including Hoyt v. Florida. If it was ever the case that women were unqualified to sit on juries or was so situated that none of them should be required to perform jury service, that time has long since passed. If at one time it could be held that Sixth Amendment juries must be drawn from a fair section of the community but that this requirement permitted the almost total exclusion of women, this is not the case today. 
* Metro Broadcasting Inc. v. FCC (1990) held that governmental favouritism for some racial groups could be justified if they were "substantially related to achievement of legitimate government interest." Overruled by Adarand Constructions Inc. v. Pena (1995) which applied strict scrutiny standard to all racial classifications.

* Other recent overruling decisions that received considerable public attention barred application of the death penalty to mentally retarded persons and to juveniles. In 1989, the court had refused to hold that execution of a mentally retarded individual (Penry v. Lynaugh 1989), or of an individual who was 16 or 17 at the time of his offence (Stanford v. Kentucky 1989), violated the Eighth Amendment; in 2002, however, the Court reversed its conclusion about execution of the mentally retarded (Atkins v. Virginia 2002), and in 2005 it did so for juveniles (Roper v. Simmons 2005). Basically, the court determined that, although execution of the mentally retarded or of juveniles had not been "unusual" in 1989, it had become so by 2002 and 2005, respectively.

* Lawrence v. Texas (2003) -where a decisive social issue was implicated in 2003, when the court, overruling a 1986 decision, struck down a State Law that prohibited private consensual, homosexual sodomy. The court justified its departure from stare decisis by concluding that the foundations in Bowers v. Hardwick (1986) had been "eroded" by subsequent decisions, that the "weakened" precedent of Bowers had been subjected to "substantial and continuing criticism, and that there had been "no individual or societal reliance... of the sort that could counsel against overturning its holding.

* In addition to the above, in the United States Supreme Court, the U.S. is most flexible in Constitutional cases. Examples, in the years from 1946-1992, the United States Supreme Court reversed itself in about 132 cases. The United States Supreme Court has explained as follows:

When convinced if former of former error, the Court has never felt constrained to follow precedents. In Constitutional questions, where correction depends upon amendments, and not upon legislative action, this Court throughout its history has freely exercised its power to examine the bases of its Constitutional decisions (Smith v. Allwright 1944).

- A clear example is where the Supreme Court in Nigeria overruled (Ariyo v. Ogele 1968) the W.A.C.A decisions in Horfall v. Amachree (1938) and Ekeleme v. Ugwuire (1942). In these cases the West African Court of Appeal had held on a case stated that where an order had been made under section 36 (1) (b) of the Native Courts Ordinance (renumbered as, s. 40 (1) (b) in the Laws of Nigeria, 1948 edition) that a suit raising an issue as to the title of land should be reheard in a Magistrate's court, the Magistrate was not exercising original jurisdiction, and had jurisdiction to hear the suit. In overruling the cases the Supreme Court observed that the W.A.C.A. gave no reasons for the decisions. A Magistrate has no original jurisdiction to hear issues as to title to land and these decisions have the effect of conferring such jurisdiction contrary to section 19 (1) of the Magistrates' Courts Ordinance. Therefore, before the Supreme Court being the highest court of the land can overrule its previous decisions, it will only do so in the interest of justice (Odi v. Osafile 1985).

* After the issuance of the Practice Statement of 1966, it enabled the House of Lords to adopt English law to meet changing social conditions. In $R v . G \& R$ (2003), the House of Lords overruled its decision in Cadwell 1981, which had allowed the House to establish mens rea ("guilty mind") by measuring a defendant's conduct against that of a "reasonable person", regardless of the defendant's actual state of mind.

\section{Conclusion}

The general rule of stare decisis is not an absolute rule; however, the courts recognize the need on occasion to correct what are perceived as erroneous decisions or to adopt decisions to changed circumstances. In deciding to overrule precedents, the courts take a variety of approaches and apply a number of different standards, many of them quite general and flexible in application. These are whether the rule has proven to be intolerable simply in defying practical workability (Swift \& Co. v. Wickham 1965); whether the rule is subject to the kind of reliance that would lend a special hardship to the consequences of overruling and add inequity to the cost of repudiation (United States v. Title Ins.\& Trust Co. 1924), whether related principles of law have so far developed as to have left the old rule no more than a remnant of abandoned doctrine (Patterson v. Mclean Credit Union 1989) and whether facts have so changed, or come to be seen so differently, as to have robbed the old rule of significant application or justification (Burnet v. Coronado Oil and Gas)

All these possibilities may be examined when the court is asked to overrule a decision.

It is not a constitutional command; as Justice Frankfurter wrote, "stare decisis is a principles of policy and not a mechanical formula of adherence to the latest decision (Helvering v. Hallock)" Although adherence to precedent is not rigidly required in constitutional cases, any departure from the doctrine of stare decisis demands special 
justification.

\section{References}

Allen, C.K., Law in the Making (7 $7^{\text {th }}$ ed. 1964) $187-235,380-382$

Bailey, H.S, The Modern English Legal System, $5^{\text {th }}$ ed. London: Sweet and Maxwell, 2007, p. 476

Blackstone, W, 1 Commentaries, 69

Cardozo, The Nature of the Judicial Process, 20, 34 (1960)

Consequences of Pragmatic Adjudication, 2002 Uttah L.Rev. 53, 66, 2002

Cosonovoy, W.S The Rehnquist Court and the End of Constitutional Stare Decisisi: Cassey, Dickerson and the Jefferson, W, Stare Decisisi, 8 Tex. Rev. L \& Pol. 271, 2004

Elias, T.O, A Nigerian Perspective in Nigerian Essays in Jurisprudence, (eds) Elias T.O and Jegede, J.I. M.I.J Publishers Ltd, 1993, p. 1

Gall, G.I., The Canadian Legal System (Toronto: The Carswell Company Ltd, 1977, p. 189

Law, C.H, A Dictionary, $2^{\text {nd }}$ ed.New York Publishing, 1910

Macey, R.J, "The Internal and External Costs and Benefits of Stare Decisis, Chicago-Kent Law Review, Vol. 65, 1989, p. 93

Moore and Oglebay, "The Supreme Court, Stare Decisis and the Law of the case, 21 Tex. L.Rev514, 539-540

Moschzisker, V, Stare Decisisi in Courts of Last Resort, 39 Harvey Law Review 409, 1924

Noland, J.D., Star Decisis and the Overruling of Constitutional Decisions in the Warren Years, 4 Valparalso

Sedler, R.A, The Michigan Supreme Court, Stare Decisisi and Overruling the Overruling, The Wayne Law Review, Vol. 55, 1911

Schauer, F, Precedent, 39, Stanford Law Review, 571, 572-573 (1986)

The Federalist, No. 78, at p. 471, 1961

Tribe, H, The Invisible Constitution 208, (2008)

Waldron, J,Stare Decisis and the Rule of Law: A Lawyered Approach, 2019

Adarand Constructions Inc. v. Pena 515 US 200, 115. SCrt. 2097 (1995)

Adigun v. A.G. of Oyo State (No. 2) (1987) 2 N.W.L.R. (pt. 56) 20

Adisa v. Oyinlola (2000) 10 N.W.L.R. (pt. 674) 116 at 171-172

Arizona v. Rumsey, 467 US 203, 2121984

Ariyo v. Ogele (1968) N.M.L.R 153

Bowers v. Hardwick 487, US 186 (1986)

Brown v. Board of Education of Topeka, Shawnee Country, Kan 347 US 483, 495, 74 S.Crt. 686, 692 (1954)

Burnet v. Coronado Oil and Gas Co. 285 US 393, 406-408, 52 S.Crt 443, 447 (1932)

Central Green Co. v. United States 531 US 425 (2001)

Clement v. Iwuanyanwu (1989) 3 N.W.L.R (Pt. 107) 39 at p. 54

Chief Effiong Le Nelson v Chief Okon Ebanga (1998) 8 N.W.L.R (pt. 563) 701

Dalhatu v. Turaki (2003) 15 N.W.L.R. (pt. 843) 322, 323

Ekeleme v. Ugwuire (1942) 8 WACA 224

Halvering v. Hallock, 309 U.S. 106, 119 (1940)

Hari Singh v. State of Haryana (1993) 3 SCC 114 at p. 120

Harrison v. Carswell (1975) 6 W.W.R.673, 25 C.C.C (2d) 186

Hayt v. State of Florida 368 U.S. 57, 82 S.Crt. 159 (1961)

Helvering v. Hallock, 309 U.S. 106, 119 (1940)

Hon v. United States, 524, U.S. 236, 251 (1998)

Horfall v. Amacheree (1938) 4 WACA 18

Lawrence v. Texas, 539 U.S. 558, 577 (2003)

Manganese Ore (India) Ltd v. Regional Assit. CST (1976) 4 SCC 124 at 127

Mantejo v. Louisiana, 129 S.Ct. 2079, 2098-99 (2009)

Metro Broadcasting Inc., v. F.C.C 497 us547, 110 SCrt. 2997 (1990)

Moradinshalal v. Fireman Insurance Coys (1988) 46 Cal. 3d 287, 296

Minersville School District v. Gobitis 310 US 586, 60 SCrt. 1010 (1966)

Mirehouse v. Rennell (1833) 1 CI. \& F 527, 546

Ndili v. Akinsunmade (2000) 8 N.W.L.R (pt. 668) 293 at 346-347

Ngwo v. Monye (1970) 1 ALL NLR 91, 100

Odi v. Osafile (1985) 1 N.W.L.R. (pt. 1) 17

Onyemeizu v. Ojiako (2000) 6 N.W.L.R. (pt. 659) 25 at p. 46

Osakue v. Federal College of Education (Technical) Asaba (2010) 10 N.W.L.R (pt. 1201) 1 at 34

Planned Paranthood of Se Pa v. Casey, 505 U.S 833, 864 (1992)

Patterson v. Mclean Credit Union, 491 US 164, 173-174 (1989) 
Payne v. Tennessee, 501 U.S 808, 827 (1991)

Penry v. Lynaugh, 492 US 302 (1989)

Plessy v. Ferguson 163 US 53716 SCrt. 1138 (1846)

R v. G \& R (2003) 2 Q.B. 331

Roe v. Wade 410 US 113 (1973)

Seminole Tribe v. Florida, 517 U.S 44, 67 (1996)

Smith v. Allwright 321, US 649, 6551944

Swift \& Co. v. Wickam, 382 US 111, 116 (1965)

Taylor v. Louisiana 419 US 522, 533-537 (1975)

Tiverton Estates Ltd v. Wearwell Ltd (1975) Ch. 146 at p. 371

United States Internal Revenue Services v. Osborne (in re Osborne ) 76 F.3 d 306, 96-1 US TaxCas (CCH), para.50 185(9 Cir. 1996)

United States v. Title Ins. \& Trust Co., 265 US 472486 (1924)

Union of India v. Raghubir Singh (1989) 2 SCC 754 at p. 766

7UP Bottling Co. Ltd. v. Abiola \& Sons Ltd. (1995) 3 N.W.L.R. (pt. 383) 257 at 279

Wamam Rao v. Union of India (1981) 2 SCC 362 at p. 392

Welch Tex. Dept. of Highways \& Public Trans 483 U.S 4681987

West Virginia State Board of Education v. Barnet 319 US 624, 63 S.Crt1178 (1943)

Woods Manufacturing Coy. Ltd v. The King (1951) S.C.R. 504 at p. 67 